\title{
Improving Low Grade Reading Ability Using Cooperative Learning Methods
}

\author{
Yunitasari \\ SD Negeri 02 Banjarsari \\ yunitasari003001@gmail.com
}

\section{Article History}

accepted 14/11/2020

approved $21 / 11 / 2020$

published $26 / 11$

\begin{abstract}
From the purpose of learning problems using the Cooperative Learning method by peeling the sequence, not only to convey information to students, it aims to convey information, among others, the formation of favorable conditions for students to improve student learning outcomes. can be developed through the Cooperative Learning method by peeling the sequence, among others, speaking, asking questions, writing, and reading. The research conducted was a Classroom Action Research (PTK) with three cycles, with each cycle consisting of two meetings. The stages of each cycle are planning, implementing actions, observing and reflecting. Each meeting is carried out a pre test and post test to determine the development of students. In the first cycle the students who completed after carrying out the post test were $59 \%$. In the second cycle students who completed after carrying out the post test were $75 \%$. In the third cycle students who completed after carrying out the post test were $85 \%$. These results indicate that thelearning model Cooperative Learning can improve the learning outcomes of lowgrade students at SDN 02 Banjasari
\end{abstract}

Keywords: Learning outcomes, cooperative learning, low class

\begin{abstract}
Abstrak
Dari tujuan pembelajaran masalah menggunakan metode Cooperative Learning dengan mengupas urutan, tidak hanya untuk menyampaikan informasi kepada siswa, hal ini bertujuan untuk menyampaikan informasi antara lain pembentukan kondisi yang menguntungkan bagi siswa untuk meningkatkan hasil belajar siswa. Dapat dikembangkan melalui metode pembelajaran kooperatif dengan mengupas serial meliputi berbicara, bertanya, menulis, dan membaca.

Penelitian yang dilakukan adalah Penelitian Tindakan Kelas (PTK) dengan tiga siklus, dengan setiap siklus terdiri dari dua pertemuan. Tahapan setiap siklus adalah perencanaan, pelaksanaan tindakan, observasi dan refleksi. Setiap pertemuan dilakukan pre test dan post test untuk mengetahui perkembangan siswa. Pada siklus I siswa yang tuntas setelah melaksanakan post test sebanyak 59\%. Pada siklus II siswa yang tuntas setelah melaksanakan post test sebanyaksiswa $75 \%$. Pada siklus III siswa yang tuntas setelah melaksanakan post test sebanyak $85 \%$. Hasil tersebut menunjukkan bahwa model pembelajaran Cooperative Learning dapat meningkatkan hasil belajar siswa kelas bawah di SDN 02 Banjarari.
\end{abstract}

Kata kunci: Hasil belajar, cooperative learning, kelas rendah

Social, Humanities, and Education Studies (SHEs): Conference Series https://jurnal.uns.ac.id/shes

p-ISSN 2620-9284 e-ISSN 2620-9292 


\section{PENDAHULUAN}

Karena pandemi Covid-19 maka Kemendikbud menentukan tata cara proses pembelajaran jarak jauh tahun ajaran 2020-2021. Pemerintah menetapkan dua model pelaksanaan kegiatan pembelajaran, yaitu pembelajaran dari rumah (BDR) untuk daerah-daerah di zone merah, orange dan kuning, dan Bembelajaran Tatap Muka (BTM) bagi daerah-daerah di zona hijau dengan mengikuti protokol kesehatan. Dalam kegiatan pembelajaran PABP terdapat materi membaca dan hafalan surah-surat pendek.Guru harus menggunakam metode menghafal yang akan diberikan kepada siswa melalui daring (ZOOM).

Salah satu tugas guru adalah mengajar, hal ini akan menyebabkan adanya tuntutan kepada setiap guru untuk menjawab pertanyaa tentang bagaimana seharusnya mengajar? Dengan kata lain setiap guru dituntut untuk memiliki kompetensi mengajar. Guru akan memiliki kompetensi mengajar jika guru paling tidak memiliki pemahaman dan penerapan secara teknis.

Berbicara mengenai keberhasilan dalam proses pembelajaran memang tidak ada habisnya, seorang guru yang sudah berupaya dalam melaksanakan proses belajar mengajar semaksimal mungkin mulai dari merencanakan pembelajaran sampai menilai hasil belajar terkadang tidak mendapatkan hasil yang maksimal seperti yang diharapkan. Dalam proses pembelajaran guru sering menemui masalah yaitu hasil belajar yang tidak sesuai dengan tujuan yang diharapkan sehingga guru berupaya untuk memperbaiki kinerja.

Penuliskan akan menjelaskan terlebih dahulu pengertian Kemampuan

Setiap melakukan kegiatan pasti diperlukan suatu kemampuan, namun apa arti kemampuan itu sendiri sering tidak diketahui.

Menurut Kamus Umum Bahasa Indonesia susunan W.J.S. Poerwadarminta yang diolah kembali oleh Pusat Bahasa Departemen Pendidikan Nasional (2007: 742) kemampuan diartikan kesanggupan, kecakapan, atau kekuatan. Menurut Nurkhasanah dan DidikTumianto (2007: 423) kemampuan diartikan kesanggupan, kecakapan, atau kekuatan. Berdasarkan dua pengertian di atas dapat disimpulkan kemampuan adalah

kesanggupan atau kecakapan untuk menguasai sesuatu yang sedang dihadapi. Dalam pembelajaran bahasa Indonesia kemampuan membaca sangat diperlukan dan harus dimiliki oleh seseorang karena kemampuan membaca merupakan dasar untuk menguasai berbagai bidang studi.

Setiap hari mungkin selama beberapa jam bisa dilakukan kegiatan membaca. Tetapi, apakah membaca itu sebenarnya? Banyak sekali batasan yang dikemukakan orang tentang membaca, tergantung dari segi mana memandangnya.Menurut Sabarti Akhadiah dkk. (1993: 22) membaca merupakan suatu kesatuan kegiatan yang mencakup beberapa kegiatan seperti mengenali huruf dan kata-kata, menghubungkan bunyi serta maknanya, serta menarik kesimpulan mengenai maksud bacaan. Sedangkan Anderson, dkk. dalam Sabarti Akhadiah (1993: 22) memandang membaca sebagai suatu proses untuk memahami makna suatu tulisan. Kemampuan membaca merupakan kemampuan yang kompleks yang menuntut kerjasama antara sejumlah kemampuan. Untuk dapat membaca suatu bacaan, seseorang harus dapat menggunakan pengetahuan yang sudah dimilikinya.

Menurut Mulyono Abdurahman (2003: 200) membaca merupakan aktivitas kompleks yang mencakup fisik dan mental. Aktivitas fisik yang terkait dengan membaca adalah gerak mata dan ketajaman penglihatan. Aktivitas mental mencakup ingatan dan pemahaman. Orang dapat membaca dengan baik jika mampu melihat huruf-huruf dengan jelas, mampu menggerakkan mata secara lincah, mengingat simbul-simbul bahasa dengan tepat dan memiliki penalaran yang cukup untuk memahami bacaan.Menurut Puji Santoso (2007: 6.3) aktivitas membaca terdiri dari dua bagian, yaitu membaca sebagai proses dan membaca sebagai produk. Membaca sebagai proses mengacu pada aktivitas fisik dan mental. Sedangkan membaca 
sebagai produk mengacu pada konsekuensi dari aktivitas yang dilakukan pada saat membaca. Pernyataan ini sesuai dengan yang termuat dalam jurnal Reading the Media (2007) reading the media is an excellent source for devising one's own media literacy curriculum, and why media literacy matters (membaca merupakan sumber yang bagus dalam memikirkan/menentukan kemampuan membaca seseorang dan mengapa kemampuan membaca tersebut berarti). Proses membaca sangat kompleks dan rumit karena melibatkan beberapa aktivitas, baik berupa kegiatan fisik maupun mental. Menurut Puji Santoso (2007: 6-3) Proses membaca terdiri dari beberapa aspek. Aspek-aspek tersebut adalah: (1) aspek sensori, yaitu kemampuan untuk memahami simbol-simbol tertulis, (2) aspek perspektual, yaitu kemampuan untuk menginterprestasikan apa yang dilihat sebagai symbol, (3) aspek skemata yaitu kemampuan menghubungkan informasi tertulis dengan struktur pengetahuan yang telah ada, (4) aspek berpikir yaitu kemampuan membuat inferensi dan evaluasi dari materi yang dipelajari, dan (5) aspek afektif, yaitu aspek yang berkenaan dengan minat pembaca yang berpengaruh terhadap kegiatan membaca. Interaksi antara kelima aspek tersebut secara harmonis akan menghasilkan pemahaman membaca yang baik, yakni terciptanya komunikasi yang baik antara penulis dengan pembaca.

Menurut Farida Rahim (2008: 2) membaca adalah suatu yang rumit yang melibatkan banyak hal, tidak hanya melafalkan tulisan, tetapi juga melibatkan aktivitas visual, berfikir, psiko linguisutik, dan metakognitif. Membaca sebagai proses visual merupakan proses menerjemahkan simbul tulis ke dalam bunyi. Sebagai suatu proses berfikir, membaca mencakup pengenalan kata, pemahaman literal, interprestasi, membaca kritis, dan membaca kreatif. Membaca sebagai proses linguistik, skemata pembaca membantunya membangun makna. Sedangkan fonologis, semantik dan fitur sintaksis membantu mengomunikasikan pesan-pesan. Proses metakognitif melibatkan perencanaan, pembetulan suatu strategi, pemonitoran, dan pengevaluasian. Membaca hendaknya mempunyai tujuan, karena seorang yang membaca dengan suatu tujuan, cenderung lebih memahami dibandingkan dengan orang yang tidak mempunyai tujuan. Dalam kegiatan membaca di kelas, guru seharusnya menyusun tujuan membaca dengan menyediakan tujuan khusus yang sesuai atau dengan membantu mereka menyusun tujuan membaca siswa itu sendiri. Menurut Farida Rahim (2008: 11) tujuan membaca mencakup: (1) kesenangan, (2) menyempurnakan membaca nyaring, (3) menggunakan strategi tertentu, (4) memperbaharui pengetahuannya tentang suatu topik,(5) mengaitkan informasi baru dengan informasi yang telah diketahuinya, (6) memperoleh informasi untuk laporan lisan atau tertulis, (7) menginformasikan atau menolak prediksi, (8) menampilkan suatu eksperimen atau mengaplikasikan informasi yang diperoleh dari suatu teks dalam beberapa cara lain dan mempelajari tentang struktur teks, (9) menjawab pertanyaan pertanyaan yang spesifik. Berdasarkan beberapa pendapat di atas dapat disimpulkan membaca adalah suatu aktivitas komplek baik fisik maupun mental yang bertujuan memahami isi bacaan sesuai dengan tahap perkembangan kognitif. Setiap pembaca memiliki tahap perkembangan kognitif yang berbeda, misalnya siswa kelas I SD perkembangan kognitifnya tidak sama dengan siswa kelas IV, V, dan VI. Sehingga bahan ajar (bacaan yang dibaca) tidak sama, harus disesuaikan dengan tingkat perkembangan kognitif yang dimiliki siswa. Ada beberap definisi tentang pembelajaran kooperatif yang dikemukakan para ahli pendidikan.

Slavin (1995) dalam Nur Asma. (2006: 11) mendefinisikan belajar kooperatif sebagai berikut "cooperative learning methods share the idea that students work together to learn and are responsible for their teammates learning as well as their own". Definisi ini mengandung pengertian bahwa dalam belajar kooperatif siswa belajar bersama saling menyumbang pemikiran dan bertanggung jawab terhadap pencapaian hasil belajar secara individu maupun kelompok. Davidson dan Kroll (1991) dalam Nur Asma. (2006: 11) mendefinisikan belajar kooperatif adalah kegiatan yang berlangsung 
di lingkungan belajar siswa dalam kelompok kecil yang saling berbagi ide-ide dan bekerja secara kolaboratif untuk memecahkan masalah-masalah yang ada dalam tugas mereka.

\section{METODE}

Penelitian ini merupakan penelitian tindakan kelas (Classroom Action Research). dengan menerapkan model pembelajaran Cooperative Learning Menurut Kurt Lewin dalam Kunandar (2011: 42) pembelajaran tindakan kelas ini terdiri dari empat tahap dasar yaitu perencanaan (planning), implementasi (akting), observasi (observasi) dan refleksi (refleksi). Analisis penelitian ini adalah analisis deskriptif kuantitatif kualitatif dimana dalam penelitian ini selain menyajikan hasil berupa data dan angka, peneliti juga menentukan bagaimana hasil penelitian tersebut diolah dengan membuat analisis dengan menerapkan model penelitian Cooperative Laearning. Penelitian ini dilakukan pada siswa Kelas II Semester I SDN 02 Banjarsari Tahun pelajaran 2020/2021 selama tiga siklus secara online menggunakan aplikasi Google Zoom dengan dua kali pertemuan pada setiap siklusnya. Siklus I dilaksanakan pada hari Senin dan Kamis 16 dan 19 November 2020. Siklus II dilaksanakan Senin dan Kamis 23 dan 26 November 2020. Siklus III dilaksanakan pada tanggal 13 dan 14 Desember 2020. Teknik pengumpulan data dilakukan dengan observasi dan tes, baik pra- test dan post test. Pengamatan meliputi observasi pelaksanaan model pembelajaran Cooperative Learning, sikap dan keterampilan siswa.

\section{HASIL DAN PEMBAHASAN}

Pada siklus I pembelajaran dilaksanakan sebanyak dua kali pertemuan, masingmasing pertemuan dilakukan pre test dan post test. Untuk mengetahui perkembangan siswa selama pembelajaran. Siklus I dimulai dengan guru membacakan teks bacaan tentang kondisi desa , siswa menyimaknya dengan seksama hingga selesai. Setelah menyimak setiap siswa membaca teks tersebut secara bergantian .Guru memberi tugas kepada peserta didik membuat kalimat yang memuat kata yang tertulis. Selanjutnya peserta didik mengamati gambar harga barang di sesuaikan dengan pecahan uang. Pembelajaran dengan model Cooperative Learning dilaksanakan dengan 4 langkah secara berurutan mulai dari Perencanaan,pelaksanaan tindakan observasi dan refleksi. Berikut ini adalah hasil belajar peserta didik pada siklus I, siklus 2 dan siklus 3 yang bisa dilihat pada tabel berikut.

Tabel 1. Hasil belajar peserta didik pada siklus

\begin{tabular}{|c|c|c|c|c|c|}
\hline No & Nama Siswa & $\begin{array}{c}\text { Nilai } \\
\text { sebelum } \\
\text { perbaikan }\end{array}$ & $\begin{array}{c}\text { Nilai } \\
\text { perbaika } \\
\text { n siklus } \\
1\end{array}$ & $\begin{array}{c}\text { Nilai } \\
\text { perbaika } \\
\text { n siklus } \\
2\end{array}$ & $\begin{array}{c}\text { Nilai } \\
\text { perbaika } \\
\text { n siklus } 3\end{array}$ \\
\hline 1 & AQAILA FIRDAUSI & 30 & 55 & 60 & 70 \\
\hline 2 & ADYNA SALMA & 30 & 60 & 70 & 80 \\
\hline 3 & $\begin{array}{l}\text { ATAYA AFRA } \\
\text { AZAHRA }\end{array}$ & 40 & 60 & 80 & 90 \\
\hline 4 & AZAHWA KANZA & 20 & 50 & 60 & 70 \\
\hline 5 & HAIKAL SARIF & 50 & 60 & 75 & 85 \\
\hline 6 & ISTIHFAR ASHARI & 50 & 60 & 80 & 90 \\
\hline 7 & KARISMA IMATUL & 55 & 65 & 80 & 90 \\
\hline 8 & KAILA SAFIRAH & 45 & 60 & 80 & 90 \\
\hline 9 & NADIN ALFITASARI & 55 & 65 & 90 & 95 \\
\hline 10 & $\begin{array}{l}\text { REFAN DIMAS } \\
\text { SETIAWAN }\end{array}$ & 45 & 60 & 75 & 85 \\
\hline
\end{tabular}




\begin{tabular}{ccccc}
\hline Jumlah & 420 & 585 & 750 & 850 \\
Rata-rata & 42 & 59 & 75 & 85 \\
\hline
\end{tabular}

Pada tabel Pada tabel di atas diketahui bahwa nilai rata-rata sebelum perbaikan 42 berarti masih jauh dari hasil yang diharapkan. Dengan kata lain penelitian belum berhasil dalam melaksanakan pembelajarannya di kelas, oleh karena ini peneliti mengadakan penelitian di kelasnya dengan bantuan teman sejawat kemudian melaksanakan perbaikan pada siklus 1 sudah ada peningkatan dengan nilai rata-rata 59. Namun dengan nilai rata-rata itu masih dirasakan bagi peneliti belum memuaskan karena masih ada beberapa siswa yang nilaianya dibawah KKM. Karena peneliti melakukan perbaikan pembelajaran lagi pada siklus 2 sudah lebih banyak mengalami peningkatan pada siklus 1 dan nilai rata-rata 75 bahkan setelah mengadakan siklus 3 hasil belajar yang diproleh oleh perserta didik mengalamai peningkatan yang signifikan yaitu nilai rata-rata 85

Pembahasan Setiap Siklus

Dari tabel tersebut dapat diketahui sebelum perbaikan pembelajaran nilai siswa sangat rendah dengan nilai 42 setelah diadakan perbaikan pembelajaran pada siklus 1 nilai rata-rata meningkat menjadi 58 tetapi peneliti masih ingin nilai yang lebih baik lagi yang sesuai dengan harapan. Akhirnya peneliti mengadakan perbaikan pembelajaran pada siklus 2 dan dari siklus 2 ini diperoleh nilai jauh diatas standart dan sesuai, dengan nilai rata-rata 75 , maka peneliti segera melakukan tindakan yaitu melakukan pembelajaran siklus 3 Alhamdulillah hasil yang diperoleh oleh peserta didik sangat memuaskan yaitu mendapatkan nilai rata-rata 85. .

Peningkatan hasil belajar mulai dari sebelum perbaikan, peningkatan pada siklus 1 dan perbaikan pada siklus 2 tidak lepas dari bantuan teman sejawat yang telah memberi bimbingan sehingga peneliti menggunaka strategi pembelajaran yang diaplikasi dengan kehidupan sehari-hari dan menggunakan metode diskusi serta memberikan kesempatan bertanya kepada siswa, dengan demikian siswa lebih mudah untuk memahami materi yang diajarkan.

\section{SIMPULAN}

Berdasarkan hasil penelitian yang telah dilakukan selama 3 siklus, maka dapat diambil beberapa kesimpulan diantaranya sebagai berikut Dengan menggunakan strategi pembelajaran yang diaplikasikan dengan kehidupan sehari-hari dapat memudahkan siswa untuk memahami dan menerima materi yang diajarkan, dengan metode Cooperative Learning siswa lebih bersemangat dan dapat berperan aktif dalam kelas,penggunaan system PAKEM dalam pembelajaran dapat menarik perhatian siswa sehingga siswa merasa senang terhadap pelajaran yang kaitannya dapat meningkatkan pemahaman siswa terhadap materi pelajaran.

\section{DAFTAR PUSTAKA}

Akhadiah dkk. (1993: 22)Anderson, dkk. dalam Sabarti Akhadiah (1993: 22)

Nurkhasanah dan DidikTumianto (2007: 423)Kamus Umum Bahasa Indonesia. Pusat Bahasa Departemen Pendidikan Nasional:jakarta

Poerwadarminta, W.J.S, (2007: 742). Kamus Umum Bahasa Indonesia. Pusat Bahasa Departemen Pendidikan Nasional:jakarta

Santoso Puji (2007: 6.3)jurnal Reading the Media (2007) reading the media is an excellent source for devising one's own media literacy curriculum, and why media literacy matters (membaca merupakan sumber yang bagus dalam memikirkan/menentukan kemampuan membaca seseorang dan mengapa kemampuan membaca tersebut berarti) 6-3 
SHEs: Conference Series 3 (3) (2020) 1374- 1379

Slavin, R. E. 2009. Cooperative Learning: Theory, Research, and Practice. Second Edition. Boston: Allyn and Bacon. 